\title{
CEO Compensation and Performance of Banks
}

\author{
Faruque Ahamed
}

\section{ABSTRACT}

\begin{abstract}
The association between CEO compensation and bank profitability has drawn substantial attention in recent years. The study analyzes the relationship between CEO compensation and bank performance in Bangladesh for 2010-2020. The variables used in the study are return on equity, CEOs salary, bonus, housing facilities, housing allowance, and foreign trips. The study uses a 2SLS estimator to remove the possible endogeneity and create an unbiased result. The results strongly suggest that the CEOs' compensation package is positively and significantly related to the bank performance. A higher compensation package motivates the executives to perform well and reduces the agency problem.
\end{abstract}

Keywords: bank profitability, bank performance, CEO compensation.
Submitted : December 29, 2021

Published : January 22, 2022

ISSN: $2507-1076$

DOI: $10.24018 /$ ejbmr.2022.7.1.1234

\section{Faruque Ahamed*}

Northern Illinois University, USA.

(e-mail: Faruque.ahamed ${ }^{\circledR}$ niu.edu)

*Corresponding Author

\section{INTRODUCTION}

The banking industry has seen exceptional growth by introducing innovative financial products and improved banking services. A bank's efficiency largely depends on the size performance of the top management and the executive committee. The compensation acts as a productive factor for most bank executives. Unstructured compensation can tempt bank executives to serve own interests rather than the shareholders' interest, increasing agency problems. When banks provide a structure compensation to reward high performance, the agency problem reduced. In recent years, a trend has shifted towards the incentive-driven compensation system rather than the standard compensation system. This encourages the top executives to show outstanding performance and profitability for the company. The adoption of the incentive-based compensation approach by the highperforming financing institutions has created a value addition standard to earn higher value for the shareholders. The Chief Executive Officer (CEO) compensation is directly linked with the financial institutions size and financial performance measured by return on assets (ROA) and return on equity (ROE). Although in Covid period the banking sector didn't perform well, most of the banks didn't focuses on curtailing the compensation package (Ahamed, 2021a). The compensation includes salary, bonuses, stock options, etc. This study focuses on the impact of CEO compensation on the profitability of large commercial banks. The research finds that the compensation of the bank CEOs is positively linked with the financial performance measured by ROA and ROE.

\section{PREVIOUS StUdies}

Stiglitz (1975) and Diamond and Verrecchia (1982) expressed the necessity of compensating executives based on the organization's performance. They found that shareholders can add value by tying the executive compensation with financial growth. The empirical research found that changing the CEO's compensation can significantly affect the firm's performance. The compensation enhances the productivity and motivation of the CEO that drives higher bank performance over the period.

Dial and Murphy (1995) uses bonuses, stock options, and other perquisites to test the relationship between performance and compensation. The author assessed compensation data for executives in 72 manufacturing firms over 1964-1981 and figured out that the total compensation of executives has a positive impact on the firm's performance. However, Jensen and Murphy (1990) analyzed the compensation data of the manufacturing firms over the period from 1974-1986. The study found a weak positive relationship between compensation and performance. Although bonuses represent CEO compensation, the authors also found that bonuses are not sensitive to performance measures.

The linkage between executive compensation and performance measure of the banks are strict because of controlling and monitoring mechanisms in the commercial banking industry. Regulatory control can impact the decisionmaking situation of CEOs. The executives must make a balance between internal and external corporate control. Weisbach (1988) found that strict external control can cause executives to make poor decisions. The regulatory barriers can dampen external control over banks. The control and monitoring mechanisms are stricter in banking than the market for corporate control for nonfinancial organizations.

Mester (1993) suggests that the regulators may discourage bank executives from taking high risks than the shareholders require. They prefer managers to ensure the proper safety and soundness of the banking industry. The author reported that bank administrative surveys of small banks found a positive and strong correlation between performance and annual bonuses. Arnould (1985) analyzed the compensation of bank CEO in 1975 and found that compensation was positively and significantly related to a performance proxy, interest, and fees on loans. The author also concluded that the banks in a 
competitive market compensate more to the CEOs than those in a monopolized market.

Deysel and Kruger (2015) analyzed the association between CEO compensation and firm performance in the banking industry in South Africa. They found a statistically significant and positive relationship between CEO compensation and banking sector market performance. However, Jegede (2012) found contrary results by investigating the effect of executive compensation structure and ownership on bank performance. The author collected data by applying a random sampling technique of 240 employees from a cross-section of banks in Nigeria. The results revealed that executive compensation structure does not affect the banks' financial performance and market value.

Guo et al. (2015) examined the relationship between executive compensation and bank performance and risk in the 2007-2008 crises for a cross-section of banks in the US. Using the z-score and stock price volatility, the authors conclude that a more significant proportion of incentive pay decreases the likelihood of a bank becoming a problem or failed institution and aligned with shareholders' interest. Doucouliagos et al. (2007) explore the association between directors' pay and performance in the Australian banking sector using panel data from 1992-2005. The research outcome discloses a strong and positive relationship between CEO remuneration and bank performance.

Molyneux and Linh (2014) studied executive compensation, board independence, and bank efficiency in China using a sample of deposit money banks from 2004 to 2011. The outcome revealed that compensation is negatively related to bank efficiency, and the situation worsens in a financial crisis. In contrast, unpaid non-executive directors on the board increase the bank's efficiency even in a financial crisis. The results are contrary to Adithipyangkul et al. (2011), where the study shows a positive relationship between executive compensation and corporate performance in China.

Ahmed (2021a) analyzed the structure of the corporate boards, audit committee and voluntary disclosure of the companies listed in the stock exchanges and found that executive compensation drives the competence of the organizations and enhance the accountability to the board members. Another study by Ahmed (2021b) assessed the capital market efficiency in the Covid-19 period and figured out that executive compensation and benefits can impact corporate efficiency at the micro-level.

Ampuero and Laietu (2009) conducted a study to identify the relationship between compensation and bank company performance in Sweden. The study uses data from 12 banks (domestic and foreign) covering a period of 2006-2008. The research concludes that net income is not associated with CEO compensation. Gregg et al. (2012) studied the relationship between executive pay and firm performance using a sample of large UK firms. The results indicated that firm size has a primary influence on the level of executive compensation. The result also shows that although total boards pay and the pay of the highest director was relatively high in the financial sector compared to other industries, the cash-plus-bonus pay-performance sensitivity of financial firms is not significantly higher than in other sectors.

Top executives' compensation package comprises a significant portion of operating expenses. Hossain and Ahamed (2015) studied the bank-specific determinants of bank profitability where operating expenses are negatively correlated with return on equity, return on assets, and net interest margin. Another study by Hossain and Ahamed (2021) investigated the relationship between bank profitability and bank-specific, industry-specific, and macroeconomic variables using unique panel data from 23 Bangladeshi banks with large market shares from 2005 to 2019. The results revealed that operating expenses have a negative and insignificant association with bank profitability.

\section{EMPIRICAL MODEL AND RESULTS}

The research uses panel data of 16 large banks in Bangladesh covering a period of 2010-2020. The banks' annual report is used to collect the CEO compensation and financial performance data. The CEO compensation structure is usually determined by the industry competitiveness and firm-specific characteristics with the regulatory authority's approval. The total CEO compensation packages include salary, bonuses, housing facilities, foreign trips, etc., which are included in the model. The multivariate factors that determine the compensation can affect each other, creating an endogeneity problem in the model. The model uses an unbiased estimator Instrument Variable to resolve the endogeneity issue and develop an unbiased estimator Instrument Variable. The housing allowances variable is used as an instrumental variable for the variable housing facilities. The variable is not in the model and is directly related to the variable housing facilities. The exogenous variables are the model's return on equity and return on assets.

\begin{tabular}{|c|c|c|c|}
\hline Variables & $\begin{array}{c}\text { Mean } \\
\text { (Std. Dev.) } \\
\end{array}$ & Min & Max \\
\hline ROE & $\begin{array}{c}0.1479 \\
(0.0712)\end{array}$ & 0.0285 & 0.3880 \\
\hline $\operatorname{lnSLR}$ & $\begin{array}{l}13.3752 \\
(0.4037)\end{array}$ & 12.4292 & 14.0620 \\
\hline $\operatorname{lnBON}$ & $\begin{array}{l}12.4234 \\
(0.6254)\end{array}$ & 11.0176 & 13.5694 \\
\hline $\mathrm{HF}$ & $\begin{array}{c}11.5938 \\
(0.3526)\end{array}$ & 9.7699 & 12.5478 \\
\hline FT & $\begin{array}{c}1.1818 \\
(1.0607)\end{array}$ & 0.0000 & 3.0000 \\
\hline HA & $\begin{array}{c}9.5143 \\
(0.5525) \\
\end{array}$ & 7.6905 & 10.4684 \\
\hline
\end{tabular}

The model equation can be written as:

$$
R O E_{\mathrm{ij}}=\alpha+\beta_{1} \ln S L R_{i j}+\beta_{2} \ln B O N_{i j}+\beta_{3} H F_{i j}+\beta_{4} F T_{i j}+\epsilon
$$

where

$$
\mathrm{HF}=\gamma+\theta_{l} H A_{i j}+e
$$

In this equation $i$ refers to a specific bank, $j$ refers to a year, $\mathrm{ROE}_{\mathrm{ij}}$ refers to bank profitability and is the observation of 
bank $i$ in a particular year $j$. and $\epsilon$ is a normally distributed random variable disturbance term or error term with zero variance. The housing facilities variable is regressed with the housing allowances variable to eradicate the possible endogeneity. $\ln$ SLR refers to the log of basic salary InBON measures the $\log$ of bonuses, FT measures the number of foreign trips each year.

TABLE II: 2SLS ESTIMATOR RESULTS

\begin{tabular}{cc}
\hline Variables & $\begin{array}{c}\text { Estimate } \\
(\text { Std. Error })\end{array}$ \\
\hline \multirow{2}{*}{$\operatorname{lnSLR}$} & $0.0808^{* *}$ \\
lnBON & $(0.0317)$ \\
$\mathrm{HF}$ & $0.0253^{*}(0.0156)$ \\
& $0.0174^{*}$ \\
$\mathrm{FT}$ & $(0.0167)$ \\
& -0.01082 \\
$* 5 \%$ Significance Level. & $(0.0073)$ \\
$* * 1 \%$ Significance level. &
\end{tabular}

The regression outcome shows that the compensation variables have a strong and positive impact on profitability. The salary of the CEOs has the most positive and significant effect on bank performance. Higher salaries create an incentive for the top executives to perform better and efficiently. The year-end bonus and housing facility are positively and significantly associated with bank performance. Bonus paid for extraordinary performance activities motivates the executives to perform better. Housing facilities create mental satisfaction and induce the CEOs to drive bank performance. The foreign tour variable has been found to have a negative and insignificant correlation with bank performance. The CEOs can't make an efficient and effective decision while staying aboard, which drags the bank performance below. Overall, the compensation has a strong and positive impact on bank profitability. Motivated CEOs can perform well to mitigate liquidity, cyber and investment risks (Ahamed, 2021b).

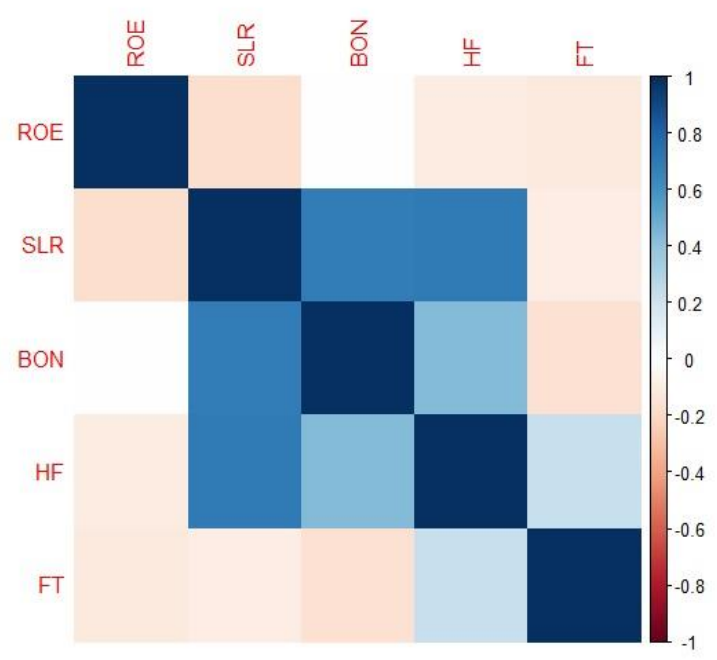

Fig. 1. Correlation Matrix.

\section{CONCLUSION}

The study examines the relationship between CEO compensation and bank performance in Bangladesh for the period of 2010-2020. The variables used in the study are return on equity, CEOs salary, bonus, housing facilities, housing allowance, and foreign trips. The study uses a 2SLS estimator using an instrument variable of housing allowance for housing facilities. Using an instrument variable removes the endogeneity from the data and makes the results unbiased. The results strongly suggest that the CEOs' compensation package is positively and significantly related to the bank performance. A higher compensation package creates an incentive for the executives to perform well and reduce the agency problem. The stakeholders can witness an acceleration in bank profitability when executives solely focus on the interest of the shareholders rather than selfinterest.

\section{REFERENCES}

Adithipyangkul, P., Alon, I., \& Zhang, T. (2011). Executive perks: Compensation and corporate performance in China. Asia Pacific Journal of Management, 28(2), 401-425.

Ahmed, F. (2021a). Corporate Boards, Audit Committees and Voluntary Disclosure: A Case Analysis on Bangladeshi Listed Companies. European Journal of Business and Management Research, 6(2), 153155 .

Ahmed, F. (2021b). Assessment of Capital Market Efficiency in COVID-19. European Journal of Business and Management Research, 6(3), 42-46.

Ahamed, F. (2021a). Macroeconomic Impact of Covid-19: A case study on Bangladesh. IOSR Journal of Economics and Finance (IOSR-JEF), 12(1), 2021.

Ahamed, F. (2021b). Determinants of Liquidity Risk in the Commercial Banks in Bangladesh. European Journal of Business and Management Research, 6(1), 164-169.

Ampuero Mellado, C., \& Laietu, A. (2009). Compensation and company performance within the banking sector: A case study on Chief Executive Officer compensation in relation to company performance measures.

Arnould, R. J. (1985). Agency costs in banking firms: an analysis of expense preference behavior. Journal of Economics and Business, 37(2), $103-$ 112.

Ayodele, J. C. (2012). Executive compensation structure, ownership and firm performance nexus: An empirical analysis. European Journal of Humanities and Social Science, 17(1), 88-888.

Deysel, B., \& Kruger, J. (2015). The relationship between South African CEO compensation and company performance in the banking industry. Southern African Business Review, 19(1), 137-169.

Dial, J., \& Murphy, K. J. (1995). Incentives, downsizing, and value creation at General Dynamics. Journal of Financial Economics, 37(3), 261-314.

Diamond, D. W., \& Verrecchia, R. E. (1982). Optimal managerial contracts and equilibrium security prices. The Journal of Finance, 37(2), 275287.

Doucouliagos H, Haman J, Askary S. (2007) Directors' remuneration and performance in Australian banking. Corporate governance: an international review., 5(6):1363-83.

Gregg, P., Jewell, S., \& Tonks, I. (2012). Executive pay and performance: Did bankers' bonuses cause the crisis? International Review of Finance, 12(1), 89-122.

Guo, L., Jalal, A., \& Khaksari, S. (2015). Bank executive compensation structure, risk taking and the financial crisis. Review of Quantitative Finance and Accounting, 45(3), 609-639.

Hossain, M. S., \& Ahamed, F. (2015). Determinants of bank profitability: A study on the banking sector of Bangladesh. Journal of Finance and Banking, 13(1), 43-57.

Hossain, M. S., \& Ahamed, F. (2021). Comprehensive Analysis on Determinants of Bank Profitability in Bangladesh. arXiv preprint arXiv:2105.14198

Jensen, M. C., \& Murphy, K. J. (1990). Performance pay and topmanagement incentives. Journal of political economy, 98(2), 225-264.

Mester, L. J. (1993). Efficiency in the savings and loan industry. Journal of Banking \& Finance, 17(2-3), 267-286.

Molyneux, P., \& Linh, H. (2014). Executive compensation, board independence and bank efficiency in China: the effects of the financial crisis. Retrieved from pdfs. semanticscholar. org.

Stiglitz, J. E. (1975). Incentives, risk, and information: notes towards a theory of hierarchy. The Bell Journal of Economics, 552-579. 
European Journal of Business and Management Research www.ejbmr.org

Weisbach, M. S. (1988). Outside directors and CEO turnover. Journal of financial Economics, 20, 431-460.

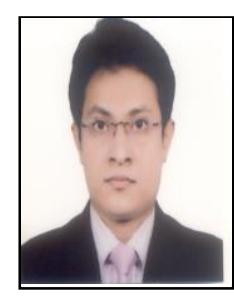

Faruque Ahamed is working as a Graduate Teaching Assistant at Northern Illinois University. He completed his graduation from the University of Dhaka, majoring in Finance. He worked in the Bangladesh Bank-The central bank of Bangladesh for almost 5 years. He was a contributor to the Financial Stability Report and Quarterly Financial Stability Assessment Report. The reports mainly focus on the country's Macroeconomic development, banking system analysis, and foreign exchange market situation. The author has a research interest in macroeconomic policies and has several publications on the subject. 